\title{
ADDENDUM
}

\section{Prosody and grammar of other-repetitions in French: The interplay of position and composition - Addendum}

\author{
R A S M U S E R S S N
}

doi: https://doi.org/10.1017/S0047404520000068 Published by Cambridge University Press, 16 March 2020.

Persson 2020 published online ahead of print. It now appears in Language in Society issue 49(4) and has been updated to include the page number for a quotation taken from another article in the same issue.

The updated passage appears on page 599: "This often involves raising problems of expectation with what the previous speaker has said, for example 'because it reports an extraordinary or remarkable fact, or because it presents an inappropriate or questionable view' (Rossi, introduction, this issue, 512)."

\section{R E F E R E N C E S}

Persson, Rasmus. "Prosody and grammar of other-repetitions in French: The interplay of position and composition." Language in Society 49(4):585-618.

Rossi, Giovanni. "Other-repetition in conversation across languages: Bringing prosody into pragmatic typology." Language in Society 49(4): 495-520.

(C) The Author(s) 2020. Published by Cambridge University Press. This is an Open Access article, distributed under the terms of the Creative Commons Attribution licence (http://creativecommons.org/ licenses/by/4.0/), which permits unrestricted re-use, distribution, and reproduction in any medium, 